\title{
Review
}

\section{The Black Jacobins reader}

Charles Forsdick and Christian Høgsbjerg (eds.)

Duke University Press, 2017, x +438 pp.,

ISBN: 978-0822362012

Contemporary Political Theory (2018) 17, S181-S184. https://doi.org/10.1057/s41296017-0155-6; published online 20 September 2017

The Black Jacobins Reader (henceforth TBJR) is the product of a 2008 conference marking the seventieth anniversary of The Black Jacobins (TBJ), the foundational text by radical anticolonial intellectual CLR James. In the introduction, we are offered a glimpse into James' mind. He remarks, 'I don't know why I was writing $T B J$ the way I did. I had long made up my mind to write a book about Toussaint L'Ouverture. Why I couldn't tell you' (p. 2). This quote and indeed, the reader as a whole, suggests that TBJ was born out of a different kind of intellectual commitment than other Marxist historical works. That intellectual commitment, argue the contributors, is one of abolishing global colonial domination.

TBJR grapples with several themes concerning both TBJ and James' political writings in general, including Haitian exceptionalism, Toussaint himself, the historical conditions which made its writing possible, its diasporic reach, and its interlocutions with key Marxist historical texts (including Trotsky's History of the Russian Revolution). TBJR is preoccupied with working out the knots in the complexity of the work, while also remaining committed to a meta-reading of the book, concerned with the question of Revolution generally, historical documentation, and contemporary struggles for liberation. What makes TBJ distinct from other Marxist texts, according to this reader, is the centrality of the question of colonial domination and of how race and class remain intertwined. Thus, it carries forward Frantz Fanon's provocation that Marxism must be 'stretched' when considering the colonial question. Finally, TBJR grapples with the afterlife of The Black Jacobins, and the manner in which the peaks in its popularity have always reflected the urgency of a given political moment in the broader struggles for black liberation (p. 27). In this regard, what TBJR manages to underscore is the extent to which $T B J$ is a work that travels well, that makes itself useful in numerous political and social contexts, a feat few works have achieved. One such exceptional thinkerwhose work also 'travels well' - is Stuart Hall, to whom the reader is appropriately dedicated.

(C) 2017 Macmillan Publishers Ltd. 1470-8914 Contemporary Political Theory Vol. 17, S4, S181-S184 
Section one includes contributions from Mumia Abu-Jamal, Carolyn Fick, and others. Abu-Jamal, one of the most cited prison intellectuals in the Black Radical Tradition, reminds us of TBJ's reach in his short (one single page) powerful reflection, '.. for any student of James, there must be many lessons, not least that of his lived experience, which proved one could be a committed activist, even a revolutionary, and yet be a scholar ... of the highest order' (p. 2). Mumia AbuJamal emphasizes that James is not only the progenitor of a long tradition of Atlantic History, but of the scholar-activist tradition more generally. Fick's reflections consist of her recollections on the theoretical vision behind her book, The Making of Haiti, which is arguably second to James' Black Jacobins in terms of its contribution to the study of the Haitian revolution. Fick describes her intellectual journey under James' guidance, and recalls James' reflections on his own over-determination of Toussaint L'Ouverture in his own work. Rather than take up the task of considering 'the masses' himself, in a show of intellectual generosity, James encouraged Fick to take on the task herself (p. 61) and chart a 'history from below'. In this regard, Fick was able to consider complexities that the first edition of the Black Jacobins could not - the 'masses', the African-born enslaved, the lesser known leaders. Her reflections reveal that James was always in conversation with his own work, and with emerging scholars advancing and challenging the intellectual project he began in 1938.

Section two, Histories and Philosophies, opens with a contribution by Laurent Dubois, arguably the most eminent scholar of Haitian history at the moment. He remarks that what struck him most when he first read $T B J$ was not the history itself, but its form: a combination of narrative staging, dialectical materialism, romanticism, and archival depth. Dubois argues that TBJ's form is what created its committed descendants (p. 88) and helped consolidate the intellectual tradition of Atlantic History. Dubois also considers James' Atlantic interventions in the French political philosophic tradition, noting that James pushed for a consideration of how Toussaint did not merely amplify within a murderous enlightenment philosophy (per Sala-Molins' argument) but rather, 'extracted from the enlightenment what the Enlightenment never dreamed' (p. 90). DuBois then considers James's fixation on Toussaint as a controlling metaphor for conflicting ideas concerning freedom: that, ultimately, representation is not freedom, a lesson that marked the future for Haiti and indeed, for the entire African diaspora.

Another standout piece from section two is David Scott's 'The Theory of Haiti', where he considers what the 'theory-problem' of Haiti is (p. 116), while also pondering the nature of the question to which Haiti offers 'the exemplary' answer. Before considering these questions, Scott problematizes the tendency to fix Haiti within an exceptional imaginary, which stems from what Michel-Rolph Trouillot calls an isolationist (as opposed to a comparativist) framework for considering Haiti, which renders it perpetually 'weird' - rather than an object of inquiry that is historically determined. Haiti, argues Scott, is inscribed within a problem-space 
where it is rendered a fundamentally anthropological theory-object (as opposed to an historical or social one). Haiti's overdetermined exceptionalism illuminates our own conceptual failings, argues Scott, and particularly a failure to recognize that all objects of inquiry have conceptual histories that service certain theoretical moves (p. 118). The paradox embedded in this need to celebrate Haiti's remarkable history while avoiding exceptionalism is produced by an emphasis on universality in the history of the Haitian revolution. An emphasis on universality and the reach for generalizability, argues Scott, paradoxically reinscribes Haiti as exceptional for this very reason. Scott concludes by noting that the motivation for any intellectual engagement with Haiti is not for the purpose of securing a more authentic theoryobject of Haiti, but rather a Haiti considered on its own terms. Nick Nesbitt echoes this sentiment in his piece, arguing that perhaps the only universal as far as Haiti is concerned, is that of a universal human contingency.

Section three, Texts and Contexts, opens with a contribution from political theorist Anthony Bogues, who argues that $T B J$ is distinctive not just for grappling with the Haitian Revolution itself, but for grappling with the 'fever and fret' of Revolution at a categorical level (p. 197). Bogues argues that TBJ accomplishes an incredibly difficult intellectual feat: that of producing a work that is at once particular and equally paradigmatic. Our predicament nowadays, argues Bogues, is that we evacuate studies of revolution of their contextual anchors and political formations. In what he calls a 'contrapuntal move', Bogues considers $T B J$ as a marker of its own historical moment (in addition to a treatise on the moment of the Haitian Revolution) concerned with possibilities. Bogues demonstrates his mastery for intellectual history as he delves into the historical conditions for writing The Black Jacobins, which he argues are two-fold: (1) the political coalitions made during Pan-African and anticolonial movement building, including organizations such as the International African Service Bureau and the International African Friends of Abyssinia; and (2) James's own work as a writer, namely his book World Revolution (1937). What James manages to do, argues Bogues, is take the commitment to periodization found in other Marxist texts (especially Trotsky's History of the Russian Revolution) and go further by considering how historical time is often compressed, how it flows, and where 'leaps' might occur (p. 204). Ultimately, Bogues argues, TBJ shows how the past is mapped and remapped onto the present and future, not as a reminder of the failure of particular political struggles but as a reminder of the very possibility of revolution and liberation always lurking beneath the surface.

Section four, Final Reflections, ends with John H. Bracey's comments on the Cuban edition of the Black Jacobins, published in 2010, the same year that Haiti suffered an earthquake that it has yet to recover from, materially and psychically. Bradley argues that Haiti is fundamental to understanding the development of the whole of the Western Hemisphere, and to that end, TBJ is a central component (p. 323). Bradley concludes by reminding readers that $T B J$ is not a perfect text, but it

(C) 2017 Macmillan Publishers Ltd. 1470-8914 Contemporary Political Theory Vol. 17, S4, S181-S184 S183 
was indeed an opening, mirroring the reality that revolutions themselves are never perfect, but are openings for all kinds of possibilities.

Those of us working and thinking in the field of Black Political Thought understand that we are in constant dialogue with the Haitian Revolution - the event, and the intellectual traditions it incubated. The challenge has always been one of imagining a global history of political thought where the Haitian Revolution takes its proper seat alongside all the major revolutions of the last three hundred years. To this end, TBJ remains unrivaled. What the TBJR accomplishes is a masterful dialogue not only with respect to $T B J$ itself, but with historical writing in general, bringing together some of the most notable voices in Haitian and Caribbean intellectual history to consider the incredible durability of James's work. TBJR also manages to stage this dialogue as one that is preoccupied with the ongoing predicament of our time - that of asking the question, time and again: what is freedom?

Bedour Alagraa

Brown University, Providence, RI 02912, USA bedour_alagraa@brown.edu 